\title{
A mídia e a representação do corpo: leitura crítica dos meios de comunicação
}

\section{The media and body image: proposal of media critical reading activities}

Roseane Andrelo ${ }^{1}$

Ligia Beatriz Carvalho de Almeida ${ }^{2}$

Resumo Neste texto são oferecidas referências teórico-práticas para o desenvolvimento de ações de mídia-educação com jovens. O objetivo é elevar a criticidade na relação do jovem com a mídia, principalmente quando há entrelaçamento entre a estetização do corpo e os temas pautados pelos meios de comunicação. Assim, expõe-se um relato de experiência desenvolvida em escola de ensino médio e apresenta-se uma sugestão de atividade a ser aplicada em ambientes educativos, ambas com foco na construção da imagem feminina.

Palavras-chave: Mídia-educação; Consumo; Representação do corpo; Beleza; Revista

Abstract In this paper, theoretical and practical frameworks for the development of actions for young people media education are offered. The goal is to improve criticality considering the relationship between young people and the media, especially when there is entanglement between aestheticization of the body and the thematic guided by the media. Thus, an experience developed in a high school is described and an activity to be applied in educational settings is presented, both having the construction of the female image as a theme.

Keywords: Media literacy; Consumption; Body representation; Beauty; Magazine

\footnotetext{
${ }^{1}$ Universidade Estadual Paulista Júlio de Mesquita Filho - Unesp, Bauru, SP, Brasil. E-mail: roseane.andrelo@faac.unesp.br

${ }^{2}$ Universidade Federal de Campina Grande - UFCG, Campina Grande, PB, Brasil. E-mail: ligiabia@gmail.com
} 


\section{Introdução}

Os meios de comunicação ocupam um papel central na sociedade, formando o mais expressivo sistema de informação, representação, identidade e expressão por meio do qual as pessoas aprendem conteúdos e valores. Exercem o papel de mediadores entre o público e o que acontece na sociedade, entretanto suas mensagens não refletem a realidade, elas a representam, fato que invalida sua comparação a uma "janela transparente", pela qual se vê o mundo (TRAQUINA, 2012).

Considerando a democratização da mídia, conforme apregoa Comparato (2000, p. 193), a comunicação social deve ser "matéria de interesse público, pertinente ao povo, não se podendo admitir nenhuma forma direta ou indireta de controle particular sobre os meios de comunicação de massa". No entanto, é comum nas democracias a esfera midiática estar constituída por grandes indústrias, financiadas pela publicidade e serem geradoras de lucro e de empregos diretos e indiretos, condição que faz com que o conteúdo gerado por esses veículos se vincule mais aos interesses mercadológicos do que às necessidades da população.

O contexto tem sido determinante para o crescimento de um movimento global, denominado "mídia-educação", fundamentado nos preceitos da cidadania, da democracia, do direito à informação e da liberdade de expressão. Organismos internacionais, como a Unesco e a Unicef, ${ }^{3}$ tratam da temática. No Brasil, isso também ocorre. O movimento busca ampliar a capacidade de expressão e elevar os níveis de criticidade dos cidadãos em face das mensagens midiáticas. Melo (2006) ressalta a necessidade de que o comunicador se engaje nesse processo. Bucci (2008) argumenta que as corporações de mídia, como parte do seu compromisso social, devem procurar qualificar a base de receptores. Emblemático é o programa Jornal e Educação, da Associação Nacional

\footnotetext{
${ }^{3}$ Unesco é a sigla utilizada para se referir a United Nations Organization for Education, Science and Culture, suas atividades voltadas à alfabetização midiática e informacional podem ser acessadas no endereço eletrônico http://www.unesco.org/new/pt/brasilia/communication-and-information/access-to-knowledge/media-and-information-literacy/. A sigla Unicef refere-se à United Nations Children's Fund, cujo trabalho pode ser conhecido em http://www.unicef.org/brazil/pt/ resources_9474.htm.
} 
dos Jornais, envolvendo empresas jornalísticas e escolas, em todo o território nacional (PAVANI, 2003), bem como a agremiação, em torno da temática, de diversos pesquisadores brasileiros e de atores sociais, como a Andi e o Instituto Alana. ${ }^{4}$

Porém, com a complexidade do fenômeno, fica a pergunta: como tratar a mídia pedagogicamente? A contribuição deste trabalho pretende ser pragmática ao oferecer referenciais para o desenvolvimento de atividades de mídia-educação. O foco recai sobre a relação do adolescente com a mídia. Uma das temáticas abordadas é preocupante, por suas consequências: a saúde, mais precisamente no que tange aos cuidados estéticos com o corpo, disseminados por revistas. Nelas persiste a alusão ao corpo como objeto de consumo. Beleza e saúde, muitas vezes, são tratadas de forma similar, por meio de receitas prontas e generalizantes que se tornam referências para os jovens. Considerando, então, o papel dos meios de comunicação na educação não formal ${ }^{5}$ dos adolescentes, é importante prepará-los para a leitura crítica da mídia. A promoção do letramento em mídia se configura como necessidade básica para o trabalho e a sociabilidade e pode ser uma estratégia importante para estabelecer laços mais estreitos entre a educação e o repertório cultural próprio da criança e do jovem.

Frente a esse cenário, os objetivos deste trabalho são: 1) descrever e discutir um relato de experiência com ações de mídia-educação voltadas à leitura crítica e criativa de revistas, promovida com adolescentes em escola de ensino médio do interior de São Paulo; e 2) propor atividade destinada também a estudantes secundários, problematizando a representação do corpo feminino.

\footnotetext{
${ }^{4}$ Consultar os sítios eletrônicos das organizações para informações: http://www.andi.org.br/infancia-e-juventude/publicacao/midia-e-educacao e http://alana.org.br/project/crianca-e-consumo/.

${ }^{5}$ Educação não formal é uma modalidade de educação, intencional, que acontece fora da escola de forma pouco estruturada e sistematizada. É o caso dos meios de comunicação de massa, dos movimentos sociais e de espaços como museus e cinemas.
} 
O material segue os parâmetros construídos em investigação sobre a literacia em mídia no ensino médio, financiada pela Fundação de Amparo à Pesquisa do Estado de São Paulo. ${ }^{6}$

\section{Contextualização: beleza, saúde e mídia}

A sociedade parece não ter plena consciência de que as mensagens midiáticas colaboram para a formação cultural e a constituição da subjetividade dos indivíduos. Os conteúdos produzidos e distribuídos por poucos acabam servindo de referência para a opinião pública. Na mídia, por vezes, cultuam-se valores de maneira descompromissada às necessidades de saúde da população. O discurso mercadológico promove uma simbiose entre beleza e saúde, se tornando senso comum acreditar que cuidar da beleza do corpo é questão de saúde. A propaganda colabora, associando a beleza à felicidade, ao bem-estar e ao sucesso pessoal e profissional. Contudo, a busca pela beleza pode ter consequências nefastas como a anorexia e o consumo inconsequente de medicamentos à base de anfetaminas, cujo uso continuado pode causar dependência e provocar efeitos colaterais, como o aumento da pressão sanguínea e distúrbios emocionais. Acrescenta-se a isso os problemas psicológicos enfrentados por aqueles que perseguem um padrão de beleza idealizado e irreal. Submeter-se à cirurgia plástica tem se tornado atitude corriqueira, inclusive entre os jovens. Entre 2008 e 2012, o número dessas cirurgias em adolescentes cresceu $141 \%$, segundo a Sociedade Brasileira de Cirurgia Plástica (2013). Esse comportamento de consumo não pode ser considerado positivo e revela a falta de preparo das partes envolvidas: população, mídia e indústria.

\footnotetext{
${ }^{6}$ A pesquisa investigou o repertório de professores e alunos do Ensino Médio sobre mídia, e o modo como eles aprendem conteúdos e conceitos relacionados a essa área. Atividades pedagógicas de mídia-educação foram criadas e avaliadas, incluindo atividades de "escrita em mídia".
} 
A indústria da beleza, por sua vez, é poderosa e lucrativa. Ela investe pesado em divulgação, sendo importante sustentáculo financeiro da mídia. Os interesses da indústria da mídia e da indústria da beleza convergem para a geração de lucro. E, na interface delas, está a publicidade. Na visão de Sant'Anna (1998), a publicidade deve fazer interessar, persuadir, convencer e levar um indivíduo à ação, despertando emoções e incentivando-o a satisfazer seus desejos. No Brasil, a audiência quantitativa se transforma em moeda de troca com verbas publicitárias, fato que faz convergir a escolha dos conteúdos editoriais para o interesse dos anunciantes, caso das revistas para adolescentes, cujas páginas reverberam as tendências da moda.

Os adolescentes estão imersos nos valores cultuados pela sociedade capitalista que vê a "redescoberta do corpo como signo de liberdade física e sexual". O corpo passa a ser um "objeto de culto narcisista [...] de ritual social" e provoca uma obsessão por recursos que potencializem ou devolvam a "juventude, elegância, virilidade/feminilidade, entre outros” (BAUDRILLARD, 1981, p. 136), modificando percepções morais e ideológicas nos indivíduos. Baudrillard ainda explica que, para a mulher, a beleza se tornou um "[...] imperativo absoluto e religioso. Ser bela deixou de ser efeito da natureza e suplemento das qualidades morais" (ibid., p. 140). Com base nessa percepção, o publicitário e a indústria da beleza trabalham para vender suas mercadorias e serviços.

Sabe-se que não há consumidor ingênuo, pois as pessoas têm a capacidade crítica de análise do texto publicitário. Apesar disso e das imagens serem interpretadas e interferirem de maneira distinta em cada indivíduo, muitas vezes, o padrão de beleza divulgado na mídia faz com que muitos se sintam inferiorizados e inseguros com sua aparência, provocando um vazio constante e um anseio por algo que nunca se concretiza. A reação de muitas mulheres, principalmente das adolescentes, é a de perseguir o padrão de beleza sugerido na publicidade, o que leva à discussão proposta: de educar para o uso crítico e criativo das mídias. 


\section{Educação para a mídia}

As mídias interferem na realidade, fornecem versões seletivas do mundo, criam representações e estereótipos. Por outro lado, o conteúdo midiático, sendo produto da ação dos homens, possui um potencial educativo que pode ser utilizado a favor da melhoria da qualidade de vida dos brasileiros. A mídia é essencial para promover o diálogo e prover o acesso à informação e, uma vez que a informação é fator determinante para o desenvolvimento pessoal e comunitário, é preciso que se saiba compreendê-la, contextualizá-la, para usá-la de forma seletiva. A análise crítica da informação pode ser desenvolvida por meio da mídia-educação.

Educação para a mídia, mídia-educação, educomunicação e media literacy são termos usados para caracterizar uma área interdisciplinar do conhecimento que se preocupa em desenvolver formas de ensinar e aprender aspectos relevantes da inserção dos meios de comunicação na sociedade. Assim, a "literacia em mídia" é o resultado esperado de ações pedagógicas, que envolvem compreensão crítica das mensagens, da função da comunicação e participação ativa na esfera da comunicação social.

Em âmbito internacional, vale mencionar o compromisso da UNESCO com objetivos de desenvolvimento global, que fez com que ela, a partir dos anos de 1960, se dedicasse à promoção da liberdade de expressão e o acesso universal à informação e ao conhecimento, fomentando a organização de espaços sustentáveis para o diálogo intercultural. Ela parte da premissa de que o acesso livre e equilibrado à informação e ao conhecimento é um componente essencial para empoderar os cidadãos e assegurar a sua participação na sociedade. Para a Organização, a mídia-educação tem função fundamental, levando os jovens a refletir sobre o papel social dos meios de comunicação e participar da esfera midiática (FRAU-MEIGS, 2006).

Educar para a mídia não é proposta inovadora entre os brasileiros. Atividades na interface da comunicação e da educação vêm sendo desenvolvidas por comunicadores e educadores no Brasil, desde o início 
do século XX, basta recordar que a primeira emissora de rádio no Brasil, a Rádio Sociedade do Rio de Janeiro, fundada por Edgar Roquette-Pinto, em 1923, teve intencionalidade educativa (FERRARETTO, 2000).

Cabe ressaltar, portanto, que a mídia-educação não deve se restringir à educação formal, tampouco a professores. Melo (2006, p. 171), pensando na ampliação da consciência crítica, na formação política e cidadã dos indivíduos, incentiva que jornalistas desenvolvam atividades educativas em escolas. Para tanto, ele oferece algumas sugestões como: levar os jovens a comparar estruturas narrativas utilizadas por diferentes veículos; analisar opiniões e padrões de referência social divulgados na mídia - o que se propõe neste trabalho - e produzir jornais. O autor argumenta: "o jornal escolar é instrumento utilíssimo para o exercício da cidadania, ou seja, para o aprendizado prático da participação social e política" (MELO, 2006, p. 171). No âmago das profissões de educador e de comunicador pode ser encontrado um objetivo comum: contribuir para elevar a qualidade de vida dos brasileiros. Assim, o comunicador atua como educador.

Apesar disso, observa-se pouca sistematização de procedimentos e de um referencial teórico capaz de nortear esse trabalho. Como consequência, no Brasil, as atividades ocorrem de forma fragmentada, à diferença do que se observa em países como Inglaterra, Canadá e Austrália, cujas experiências possibilitam a observação da evolução dos paradigmas em mídia-educação (BUCKINGHAM, 2003), como se segue:

- Anos 30: educar para a mídia significava inocular as pessoas contra seus efeitos nocivos;

- Anos 60: a partir dos estudos culturais propunha-se criar condições para que se refletisse sobre o modo como as pessoas conviviam com as mídias;

- Anos 80: o estudo das mídias passou a ser incluído formalmente na educação escolar, em disciplina específica (media studies) ou em atividades propostas por outras áreas do currículo;

- Época atual: sob a perspectiva dos estudos culturais e articulando-se às inovações tecnológicas, a preocupação é preparar os jovens 
para usufruir, de modo consciente e proveitoso, dos benefícios que as mídias podem oferecer.

Contudo, na atualidade, mesmo os paradigmas considerados superados coexistem nas práticas docentes, demonstrando a dificuldade no trato da temática.

\section{Referencial teórico e metodología para a mídia-educação}

Uma das preocupações do educador é delimitar o objetivo da intervenção educativa. Os estudos britânicos propuseram que a educação para a mídia fosse norteada pela aquisição dos seguintes conceitos-chave:

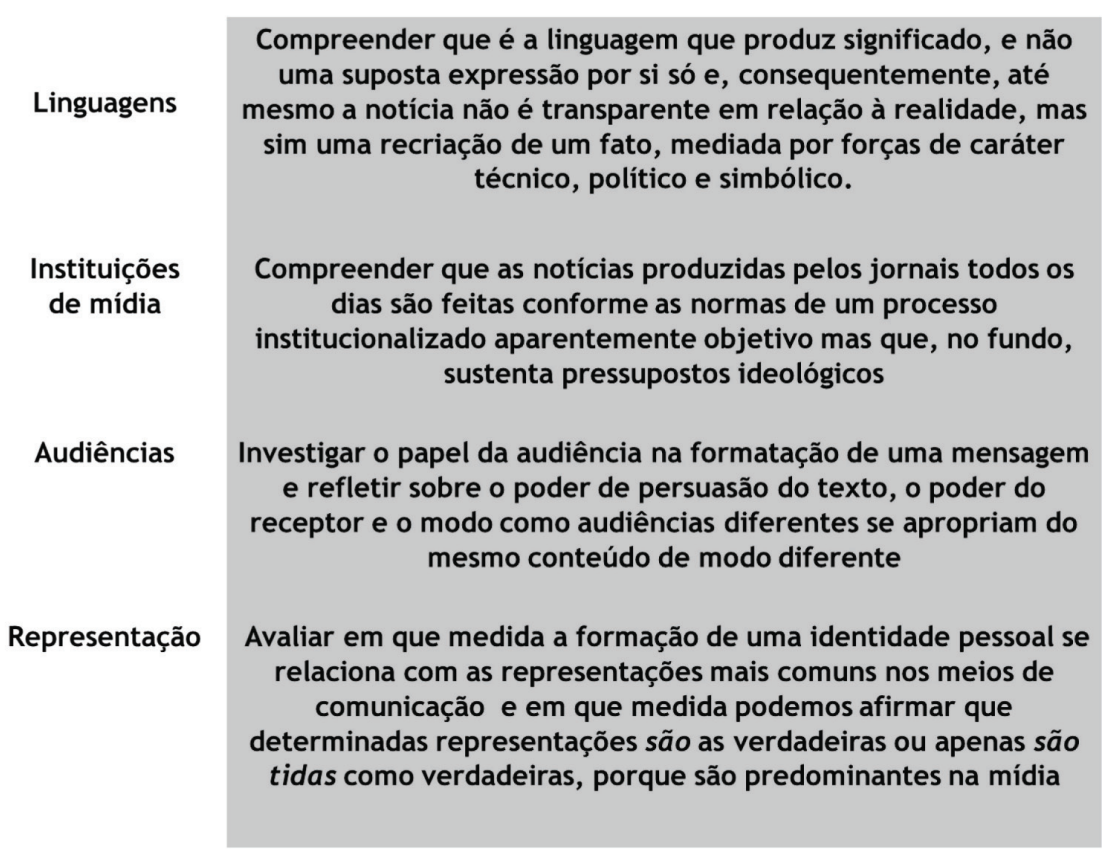

Figura 1: Conceitos-chave em mídia-educação

Fonte: Mídia na Educação (ANDRELO, SIQUEIRA, 2013) 
O conceito "representação" será mais detalhado por ser o foco da aprendizagem, tanto na experiência relatada quanto na proposta de atividade delineada, bem como a metodologia de análise de texto. Afinal, os estereótipos de gênero ocupam papel central nas discussões.

O conceito "representação" surge amparado nas teorizações de Hall (2005) e Masterman (1989) e denomina as proposições de sentido oferecidas pelas instituições de mídia, questionando a forma como a mídia retrata determinados grupos, comunidades, experiências, ideias ou temas, tendo por base uma perspectiva ideológica ou valor específico que, no caso da publicidade, é o despertar do desejo de consumo.

Hall (2005) adverte que não se deve adotar a perspectiva da existência de uma única realidade com a qual um texto de mídia possa ser comparado, nem permitir que se naturalize uma verdade apregoada por ela. Afinal, forças ideológicas, políticas e mercadológicas controlam os meios de comunicação em prol de seus interesses. Assim, há sistemas de representações que se articulam para criar significados culturais por meio dos textos midiáticos visando elaborar perspectivas de senso comum, demonstrar que certas práticas são naturais. Exemplificando: a representação do ato de comemorar na mídia é constantemente atrelada às práticas sociais de consumo de álcool e ainda que, na realidade, algumas pessoas comemorem bebendo, não se deve aceitar esse conceito como representativo do ato de comemorar.

Há produtos midiáticos de diferentes gêneros: noticiosos, publicitários docudramas, comédia, musical, reality shows. Quer se tratem de produções ficcionais, ou não, criam expectativas no receptor ao estabelecerem diferentes graus de relação com a realidade. Contudo, muitas vezes, o receptor tem dificuldade em identificar os limites entre ficção e realidade e, ao trabalhar o conceito "representação", espera-se que o jovem adquira capacidade de fazê-lo, refletindo sobre os seguintes aspectos: 
- Realismo: identificar como a mídia tenta parecer verdadeira. Ao identificar os diferentes gêneros e conteúdos midiáticos, suas funções e objetivos, irá analisar se o texto deveria ser real e entender porque uns parecem mais e outros, menos reais.

- Presença e ausência: perceber o que e quem é incluído e excluído do mundo da mídia. Quem fala e quem é calado, o que se fala e o que se omite.

- Tendenciosidade e objetividade: identificar se os textos transmitem visões parciais da realidade, se são balizados por valores morais e políticos.

- Estereótipos: compreender como a mídia representa determinados grupos e se o faz de forma realista.

- Interpretações: analisar como as audiências aceitam determinadas representações como verdadeiras e rejeitam outras.

- Influências: identificar como as representações de mundo propostas afetam nossa percepção sobre determinados grupos, profissões ou assuntos.

Quanto à metodologia, aspectos como: conceito-chave a ser estudado, tempo, idade dos estudantes e recursos disponíveis devem ser considerados para a sua definição. São abordagens bem delimitadas no bojo da mídia-educação: análise de texto e de contexto, estudo de caso, produção de textos, simulação de rotinas de produção midiática e tradução (ALMEIDA, 2013).

Nas atividades aqui discriminadas optou-se pela análise de texto. Ela é realizada em três etapas:

A. Descrição (denotativa) - elencam-se os elementos que compõem o texto analisado, o que leva à observação minuciosa de partes e detalhes contidos na imagem analisada.

B. Significação (conotações e associações) - analisam-se isoladamente os elementos (música, efeito sonoro, silêncio, iluminação) que compõem o texto, fazendo correlações externas e subjetivas com o contexto. A intertextualidade também é importante: lembrar-se de outros textos aos quais o texto em questão possa se referir. 
C. Julgamento (juízos de valor, ou ideológicos) - verifica-se a associação dos elementos textuais com qualidades identificadas como positivas (ex: natural, sexy, científica, atrativa), constatando os apelos existentes. Finaliza-se, concluindo acerca da eficácia dos apelos e argumentos contidos.

Seja qual for a metodologia escolhida, é importante que se parta sempre do reconhecimento e validação do conhecimento prévio do estudante, para evitar o distanciamento entre jovens e adultos, pois o prejulgamento do adulto quanto ao gosto midiático dos jovens irá apenas impedir a interlocução (BUCKINGHAM, 2003). Nas atividades apresentadas, o objetivo é refletir sobre a indústria da beleza.

No que diz respeito ao público escolhido para a análise e para a elaboração da atividade, cabe ressaltar que, na adolescência, o jovem ingressa em um estágio de desenvolvimento cognitivo denominado por Piaget (1976) como operatório-formal, estando pronto para a elaboração do pensamento abstrato, conceitual, passa a considerar a existência de diferentes pontos de vista sobre um mesmo fenômeno, consolidando a base para o desenvolvimento do raciocínio lógico, hipotético, sistemático e científico. Está pronto, então, para refletir sobre as motivações que impulsionam a criação e a divulgação das mensagens publicitárias, mas tem de ser guiado nesse processo de desvendamento.

$\mathrm{Na}$ abordagem pedagógica ao texto publicitário, com base nas teorizações de Vygotsky (1992), considerou-se que o caráter da aprendizagem é eminentemente social, produto da interação entre os sujeitos e a cultura. Para ele, há dois estágios de desenvolvimento: o real e o potencial. Assim, a mediação com intencionalidade educativa fará o sujeito avançar para além do seu desenvolvimento atual. Dessa forma, atividades reflexivas desenvolvidas coletivamente, promovidas por um sujeito mais experiente, permitirão o despontar do pensamento crítico individual e coletivo. Na adolescência, o jovem precisa do suporte do seu grupo, o conhecimento gerado no seio de sua comunidade tende a ser validado coletivamente, o que se aplica à atividade ora proposta. 
É nesse contexto educacional que pode ser inserido o texto publicitário. Afinal, na Perspectiva Construtivista Sociointeracionista, a pedagogia também deve ser baseada na aprendizagem por descoberta e, portanto, considerar como fundamental o interesse dos alunos, que aprendem pela motivação e pela experiência ativa. Desta forma, o aporte decisivo da educação nova deve ser sublinhado, porque ele está sempre presente nos programas de educação às mídias, situando-se principalmente sobre o plano da relação aluno-professor, na construção dos saberes, por parte do jovem, de suas motivações, de suas interrogações (GONNET, 2001).

Malitza (1984) propõe um método pedagógico que consiste em ensinar com a ajuda de elementos de organização prévios. Parte da premissa de que a aprendizagem depende da experiência pessoal do indivíduo, da integração subjetiva de dados novos aos conhecimentos anteriores. Por esse método, cada lição deve ser precedida pela apresentação de um elemento de organização, introduzindo o aluno no contexto no qual ele integra o novo conteúdo. No caso dos exemplos escolhidos para análise, eles têm como vantagens o fato de assegurar um componente afetivo ao novo conteúdo, fazendo apelo não só à estrutura cognitiva do indivíduo, mas também à sua experiência socioafetiva, aos seus interesses e à sua motivação; são acessíveis a todas as idades e se prestam a todos os tipos de conteúdos. Dão vários pontos de apoio para assimilação de sentido, pela quantidade de detalhes divulgados.

No que tange especificamente ao texto publicitário, sabe-se que "através da diversidade, a publicidade desenha o retrato de certa sociedade, com sua economia, suas complexidades, sua cultura, seus modos..." (CLEMI, 2000, p. 8, tradução nossa). Mais do que isso, o texto publicitário não é transparente e, tampouco, permite uma única interpretação. "A publicidade é mais complexa do que parece. As mensagens que ela veicula podem, às vezes, ser interpretadas de diferentes maneiras e elas têm alcance maior do que se poderia pensar" (CLEMI, 2000, p. 8, tradução nossa).

Esse contexto coloca a publicidade como um possível conteúdo educativo, uma vez que deve se desenvolver a capacidade crítica de 
crianças e adolescentes face às mensagens publicitárias. Conforme defende o CLEMI (Centre de Liaison de l'Enseignement et des Médias d'Information), órgão ligado ao Ministério da Educação francês, os jovens devem ter atitude ativa e não passiva face ao fenômeno publicitário.

Como será explicitado a seguir, as atividades apresentadas consideraram essas situações: todas elas foram realizadas em grupo, a partir de uma abordagem que respeita a cultura na qual os jovens estão inseridos. Ou seja, não houve discurso prévio sobre conceitos de estética em revistas adolescentes ou mesmo sobre o papel da publicidade. Aos jovens, coletivamente, foi dado o direito de analisar e refletir sobre os exemplos escolhidos. Posteriormente, com a metodologia de mídia-educação aplicada ao material, houve meios de sistematizar as discussões, conforme será demonstrado a partir do próximo item.

\section{Relato de experiência}

As capas de revista sintetizam o conceito de estética corporal, estampando fotos de pessoas famosas. A atividade foi proposta ao constatar-se, por meio de uma análise acadêmica de capas de revistas femininas, que entre os diversos exemplares estudados nenhum havia trazido na capa uma modelo negra, japonesa, ou de qualquer raça diferente da branca e que sessenta por cento das modelos retratadas possuíam olhos claros (FERRARINI, 2011). A comparação entre diversas capas revela o sentido de produção em série adotado pelas editoras: o layout utilizado é quase sempre o mesmo, os conteúdos e o padrão de beleza das mulheres nelas estampadas se assemelham.

Assim, com uma turma de estudantes de ambos os sexos do segundo ano do ensino médio, foram estudadas e comparadas várias capas de revista. A atividade permitiu duas análises: da mídia em si e da representação de corpo e beleza. O roteiro de análise seguiu as três etapas: denotativa, conotativa e de julgamento. Na primeira, os alunos descreveram, livremente, todos os elementos contidos nas capas, tais como as chamadas de matérias, com os devidos destaques; a foto ou ilustração 
presente, indicando gestos, roupas, acessórios, características físicas e o fundo, com as cores, iluminação. Posteriormente, passou-se à análise conotativa ou associativa, refletindo isoladamente sobre cada elemento, fazendo correlações externas e subjetivas com o contexto e relacionando as capas umas às outras, identificando semelhanças. Por fim, fez-se o julgamento, emitindo juízos de valor ou ideológicos. Pôde-se verificar a existência de associações com qualidades reconhecidas socialmente como positivas (natural, sexy, científica, transformadora, atrativa), constatando os apelos existentes.

A seguir, são apresentadas duas capas de revista para exemplificar o percurso analítico.

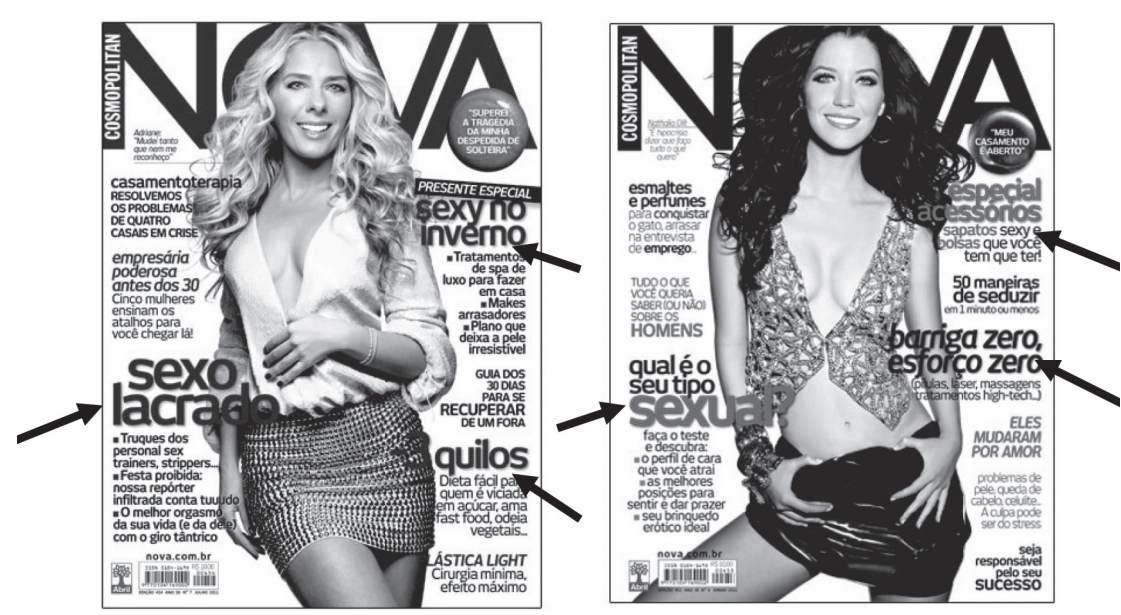

Figura 2: Edição 454 de julho e edição 453 de junho de 2011 da revista Nova Fonte: Sítio eletrônico da revista Nova (2013).

Denotação: mulheres altas, magras, olhos claros, cabelos bem cuidados, sorrindo, com grande parte do corpo à mostra, vestindo blusas cavadas, saias curtas e acessórios femininos. Os temas abordados são: comportamento, sexo, dieta, dicas de beleza e de moda, fórmulas para conseguir o corpo ideal, e a vida pessoal de artistas. As matérias divulgadas prometem a fórmula do sucesso e da felicidade. 
Conotação: a imagem de ambas está centralizada na capa, ocupando o primeiro plano. Insinuam estar se despindo. A iluminação recai sobre os seios, parcialmente à mostra. Parecem estar bem à vontade e satisfeitas. Em ambos os casos, o corpo das duas está rodeado por chamadas de matérias, mas é notório que aquelas escritas em tamanho maior se refiram a sexo e corpo. Há coincidência no posicionamento das chamadas para os mesmos assuntos em ambas as capas, o que demonstra o aproveitamento de um mesmo modelo de diagramação, típico da economia de trabalho em série.

Julgamento: as mulheres aparentam estar realizadas porque alcançaram o perfil ideal de mulher, sendo profissionalmente bem-sucedidas, o que permite que usem roupas de grife. Têm um relacionamento amoroso e sexual pleno, conquistaram e mantêm um corpo perfeito de acordo com os padrões da moda. O padrão de corpo divulgado corresponde ao da mulher europeia ou estadunidense.

A discussão caminhou para a reflexão sobre o que é ser belo e o que é ter um corpo saudável. A professora inseriu informações sobre a noção de belo na história, indicando como a mídia colabora para disseminar essas representações, fato que se tornou evidente pela análise desenvolvida, ao se expor claramente o conceito de produção capitalista industrial utilizado nas editoras responsáveis pelos títulos em análise. Os jovens compreenderam que os conceitos foram construídos pela linguagem midiática, deixando de concebê-los como algo natural. Ao final da atividade, muitas das jovens espontaneamente confessaram, não muito satisfeitas, ter perdido grande parte do encantamento que as envolvia na leitura das revistas.

$\mathrm{Na}$ ocasião em que a atividade foi realizada não houve tempo disponível, porém, para incrementar o percurso de aprendizagem, os alunos poderiam ter sido incentivados a realizar um trabalho prático, reformulando a capa da revista, sugerindo temas ligados à saúde e à beleza, a partir de preceitos que julgassem éticos. Poderiam redigir as chamadas das matérias, indicando uma imagem (ilustração ou foto) para ser inserida. Caso o trabalho fosse realizado em grupos, poderiam comparar 
as diferentes propostas a partir da apresentação oral de cada equipe, momento em que justificariam as opções feitas, refletindo sobre suas escolhas e as dos outros grupos.

\section{Proposta de atividade didática}

A partir do relato e da fundamentação teórica, propõe-se uma atividade visando despertar a leitura crítica e criativa da mídia, sobretudo no que diz respeito à representação do corpo feminino, em anúncios publicitários, trabalhando o conceito-chave de representações e a metodologia de análise textual. Desta vez, no entanto, a visão não é mais quantitativa e sim qualitativa. É pertinente mostrar aos alunos que os anúncios publicitários usam apelos e argumentos para conquistar consumidores. Para isso, são direcionados a determinados públicos e usam estratégias diversas para conquistá-los.

Foram escolhidos anúncios que utilizam a representação da mulher para vender suplementos alimentares, tema relevante para discussão com jovens.

O Quadro 1 apresenta a atividade proposta:

\begin{tabular}{|l|l|}
\hline Atividade & $\begin{array}{l}\text { - Análise de anúncios publicitários que utilizam a imagem } \\
\text { de mulheres. }\end{array}$ \\
\hline Nível & - Jovens do ensino médio. \\
\hline $\begin{array}{l}\text { Competências } \\
\text { a serem adquiri- } \\
\text { das, em diversos } \\
\text { níveis: represen- } \\
\text { tação do corpo, } \\
\text { desenvolvimento da } \\
\text { criatividade, educa- } \\
\text { ção às mídias etc. }\end{array}$ & $\begin{array}{l}\text { - Compreender como os anúncios constroem representa- } \\
\text { çõe corpo feminino; } \\
\text { - Identificar os elementos que compõem as peças publicitá- } \\
\text { - Selecionar, organizar, relacionar, interpretar dados e in- } \\
\text { formações representados de diferentes formas (texto, foto, } \\
\text { - Desenvolver a capacidade de argumentação, de pesquisa e } \\
\text { de trabalho em grupo; } \\
\text { - Aplicar conceitos de várias áreas do conhecimento para a } \\
\text { compreensão de produção de anúncios publicitários. }\end{array}$ \\
\hline
\end{tabular}




\begin{tabular}{|c|c|}
\hline Objetivos & $\begin{array}{l}\text { - Promover a leitura crítica das mídias, especificamente de } \\
\text { anúncios publicitários; } \\
\text { - Distinguir linguagem verbal e não verbal; } \\
\text { - Refletir sobre a construção, pela mídia, das representações } \\
\text { do corpo feminino. } \\
\text { - Estabelecer relações entre os apelos veiculados pelos } \\
\text { anúncios e as condições necessárias à manutenção de uma } \\
\text { vida saudável. }\end{array}$ \\
\hline $\begin{array}{l}\text { Conteúdos } \\
\text { trabalhados }\end{array}$ & $\begin{array}{l}\text { - Representação do corpo feminino; o papel da publicidade } \\
\text { na construção desses conceitos e a linguagem verbal e não } \\
\text { verbal (a combinação desses elementos na construção das } \\
\text { peças). }\end{array}$ \\
\hline Atividade & $\begin{array}{l}\text { 1. Depois de apresentar os anúncios, os alunos, divididos } \\
\text { em grupos, devem descrever os elementos contidos nas pe- } \\
\text { ças: textos, com tamanho das letras; imagens; cores. } \\
\text { 2. Em um segundo momento, devem refletir sobre cada ele- } \\
\text { mento, fazendo correlações subjetivas com o contexto (por } \\
\text { que a escolha daquela mulher? Como ela foi retratada?). } \\
\text { 3. Julgamento, emitindo juízo de valor e refletindo sobre } \\
\text { aspectos éticos envolvidos na construção daquela peça, } \\
\text { principalmente no que diz respeito ao apelo utilizado; } \\
\text { devem, ao final, refletir sobre a forma como a mulher é } \\
\text { representada em cada uma delas e se as facetas propostas } \\
\text { correspondem à realidade, assim como concluir, do ponto } \\
\text { de vista da saúde, qual influência as peças podem exercer } \\
\text { sobre o comportamento dos leitores. } \\
\text { 4. A partir da discussão feita, os alunos desenvolvem a propos- } \\
\text { ta de um novo anúncio, escolhendo uma entre as temáticas } \\
\text { apresentadas, norteados por princípios éticos e saudáveis. A } \\
\text { produção prática do anúncio pode ser realizada, porém não } \\
\text { é essencial, sendo suficiente o seu planejamento. }\end{array}$ \\
\hline Materiais & $\begin{array}{l}\text { - Anúncios publicitários que utilizem a imagem de } \\
\text { mulheres. }\end{array}$ \\
\hline
\end{tabular}

Quadro 1: Ficha pedagógica

Fonte: Elaborado pelas autoras. 
As figuras 3 e 4 trazem sugestão de peças publicitárias para a atividade:

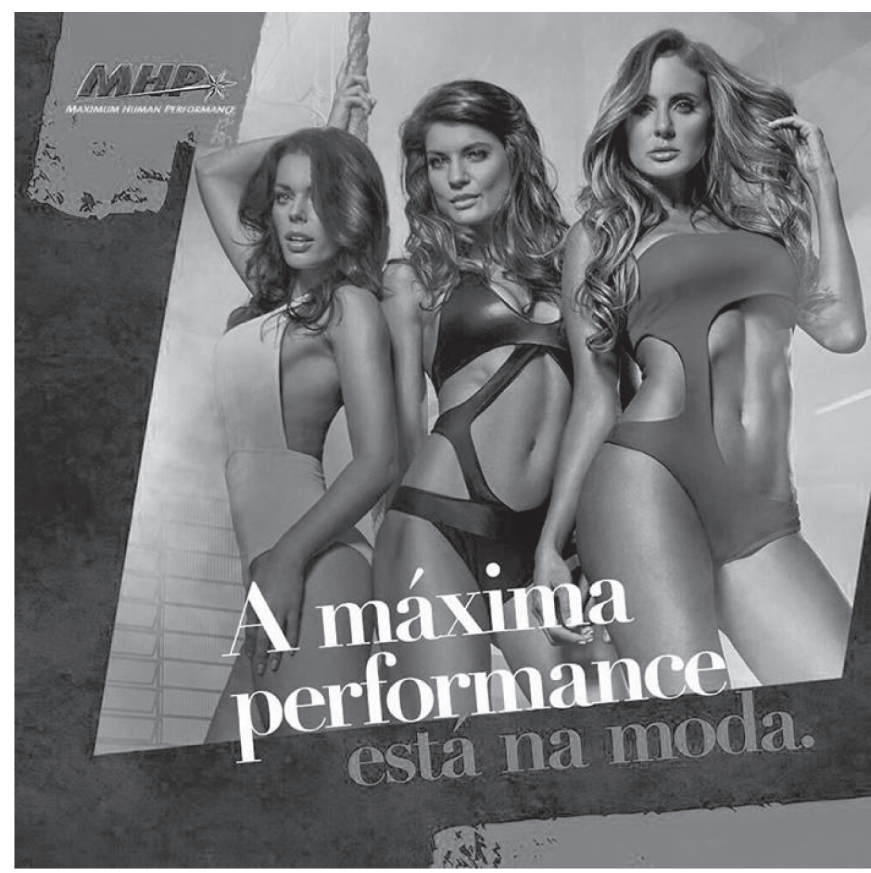

Figura 3: Publicidade do suplemento MHP (Maximum Human Performance) Fonte: By Marina, 2015.

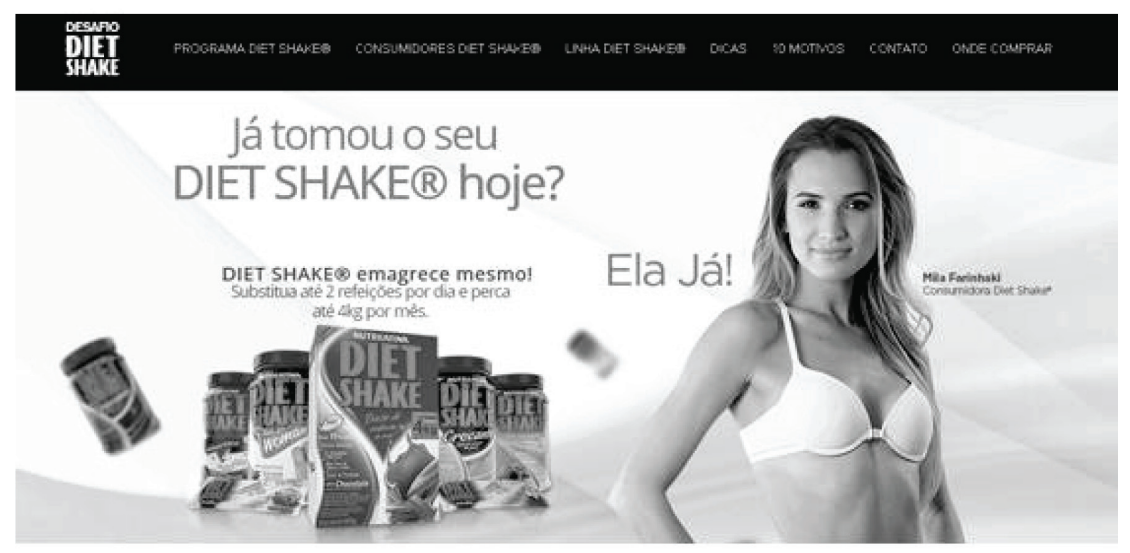

Figura 4: Publicidade do Diet Shake Fonte: Diet Shake, 2015. 
O percurso analítico revelará facetas do estereótipo frequentemente atribuído à mulher na sociedade brasileira. A temática pode ser expandida demonstrando a existência de processos semelhantes de estereotipação vinculados às diferentes etnias, aos portadores de orientações sexuais não convencionais, aos considerados magros, gordos, baixinhos etc.

\section{Considerações finais}

A centralidade que a mídia ocupa na sociedade, a responsabilidade social das empresas de mídia e dos comunicadores e a não transparência dos produtos midiáticos são argumentos que justificam a necessidade das atividades de mídia-educação, quando se propõe formar cidadãos. Não se trata de "inocular" anticorpos nos jovens a fim de torná-los imunes ao que é divulgado pelos meios de comunicação, mas de formar leitores críticos e criativos de jornais, revistas, sites, emissoras de rádio e de televisão.

Além disso, ao trabalhar com o preceito de educação às mídias, pautam-se nas escolas importantes debates como sexualidade, beleza, saúde, meio ambiente entre outros. Salienta-se que fornecer material pedagógico é um dos elementos necessários para a implantação de uma política educacional de mídia-educação.

Considerando o potencial de educação não formal dos meios de comunicação, não é possível debater, na escola, assuntos tratados por eles, sem considerar o repertório que alunos e professores trazem e que, muitas vezes, são formados pelo que consomem na mídia.

Nesse contexto, destaca-se a noção de representação, ou seja, a forma como os meios de comunicação retratam pessoas, grupos sociais, lugares, objetos e situações. E esse conceito é nítido, sobretudo, no gênero publicitário que, com pouco espaço e tempo, utiliza apelos para vender produtos e serviços. Ter essa noção é essencial para ser um leitor crítico e criativo.

A experiência com capas de revistas femininas, realizada com alunos do ensino médio, relatada sinteticamente neste artigo, permite várias reflexões. Destaca-se o interesse demonstrado pelos adolescentes em participar da análise do material e os relatos espontâneos apresentados 
ao final, indicando mudanças na forma de ler produtos com os quais estavam habituados.

Diversas temáticas podem ser trabalhadas de forma educativa recorrendo à educação às mídias, permitindo elevar os patamares de criticidade entre os jovens para que, ainda que diante da sedução da linguagem publicitária, venham a assumir um compromisso com a sua própria saúde.

O que se pretende com a educação para a mídia é construir uma relação mídia/anunciante/sociedade norteada pela democracia e orientada para o desenvolvimento social e para o consumo consciente. Em um país como o nosso, com dimensões continentais, a mídia tem papel essencial para viabilizar o diálogo e a participação da população nos assuntos coletivos, políticos e culturais. Tornar a mídia-educação acessível aos cidadãos é fator-chave para a formação da massa crítica necessária à consolidação do diálogo e de trocas construtivas interculturais e assegurará que o Brasil ocupe posição estratégica no competitivo cenário internacional.

\section{Referências}

ALMEIDA, L. B. C. Educação para a mídia. Disponível em: http://bit.ly/k0gcuU. Acesso em: 16 ago. 2013.

ANDRELO, R.; SIQUEIRA, A. B. Mídia na educação. Bauru: Universidade do Sagrado Coração. Disponível em: http://www.usc.br/midiaeducacao/conceitos.html. Acesso em: 16 ago. 2013.

BAUDRILLARD, J. A sociedade de consumo. Lisboa, Portugal: Edições 70, 1981.

BUCCI, E. A imprensa e o dever da liberdade: a responsabilidade social do jornalismo em nossos dias. In: CANELA, G. (Org.). Políticas Públicas Sociais e os Desafios para o Jornalismo. São Paulo: Cortez, 2008.

BUCKINGHAM, D. Media education: literacy, learning and contemporary culture. Cambridge: Polity Press, 2003.

BYMARINA. Top models brasileiras se tornam garotas-propaganda de marca americana de suplementos. Disponível em: http://bymarina.com.br/top-models-brasileiras-se-tornamgarotas-propaganda-de-marca-americana-de-suplementos/. Acesso em: 8 jun. 2015.

CLEMI (Centre de Liaison de l'Enseignement et des Médias d'Information). Lire et comprendre la publicité. Paris: Retz/HER Paris, 2000. 
COMPARATO, F. K. A democratização dos meios de comunicação de massa. In: BUCCI, E. (Org.). A TV aos 50: criticando a televisão brasileira no seu cinquentenário. São Paulo: Perseu Abramo, 2000.

DIET SHAKE. Desafio Diet Shake. Disponível em: http://dietshake.com.br/. Acesso em: 8 jun. 2015.

FERRARINI, D. C. P. A imagem de mulher nas revistas Nova e Gloss. 2011.57 f. Trabalho de conclusão de curso (graduação em Jornalismo) - Universidade Sagrado Coração, São Paulo, 2011.

FERRARETTO, L. Artur. Rádio: o veículo, a história e a técnica. Rio de Janeiro: Sagra, 2000.

FRAU-MEIGS, D. (Ed.). Media Education: a kit for teachers, students, parents and professionals. Paris: Unesco, 2006.

GONNET, J. Éducation aux médias: les controverses fécondes. Paris: Hachette Éducation, 2001.

HALL, S. Encoding/Decoding. In: HALL, S. et al. (Orgs.). Culture, Media, Language. Centre for Contemporary Cultural Studies. Londres: Routledge, 2005. p. 117-127.

MASTERMAN, L. Media Awareness Education: eighteen basic principle. Center of Media Literacy, 1989. Disponível em: http://www.medialit.org/reading-room/media-awareness-education-eighteen-basic-principles. Acesso em: 24 out. 2010.

MALITZA, M. Apprentissage, compréhension et moyens de communication. In: MORSY, Zaghloul. L'éducation aux médias. Paris: Presses Universitaires, 1984.

MELO, J. M. Teorias do jornalismo: identidades brasileiras. São Paulo: Paulus, 2006.

NOVA. Capas. Disponível em: http://www.nova.abril.com.br. Acesso em: 21 abr. 2013. PAVANI, C. (Org.). Jornal: (In) Formação e ação. São Paulo: Papirus, 2003.

PIAGET, J.; INHELDER, B. Da lógica da criança à lógica do adolescente: ensaio sobre a construção das estruturas operatórias formais. São Paulo: Pioneira, 1976.

SANT"ANNA, A. Propaganda: Teoria, Técnica e Prática. 7. ed. São Paulo: Pioneira, 1998. SOCIEDADE BRASILEIRA DE CIRURGIA PLÁSTICA. Dados estatísticos. Disponível em: http://www2.cirurgiaplastica.org.br/wp-content/uploads/2012/11/sbcp_isaps.pdf. Acesso em: 17 jul. 2013.

TRAQUINA, N. Teorias do jornalismo: porque as notícias são como são. v. 1. Florianópolis: Insular, 2012

VYGOTSKY, L. S.; LURIA, A. R.; LEONTIEV, A. N. Linguagem, desenvolvimento e aprendizagem. São Paulo: Ícone Editor, 1992.

Data de submissão: 07/07/2014

Data de aceite: 22/06/2015 